\title{
The Justice and Development Party in Moroccan Local Politics
}

Article in The Middle East Journal · January 2015

DOI: $10.3751 / 69.1 .12$

CITATIONS

5

2 authors:

Miquel Pellicer

University of Duisburg-Essen

23 PUBLICATIONS 132 CITATIONS

SEE PROFILE
READS

745

(2) Eva Wegner

University College Dublin

30 PUBLICATIONS 252 CITATIONS

SEE PROFILE

Some of the authors of this publication are also working on these related projects:

Project Inequality in South Africa View project

Project Clientelism View project 
(C) Middle East Institute. This article is for personal research only and may not be copied or distributed in any form without the permission of The Middle East Journal.

\title{
The Justice and Development Party in Moroccan Local Politics
}

\section{Miquel Pellicer and Eva Wegner}

\begin{abstract}
This article analyzes the performance of the Islamist Justice and Development Party (PJD) in Moroccan local politics from 2003 to 2009, using a variety of data sources including interviews, municipal budgets, and audit reports. We find that the PJD's campaign and candidates were significantly different from Moroccan political norms. The outcomes of audits and budget patterns show governance in towns where the PJD was elected differed only in those where the party had high electoral support in 2003, allowing it to govern with a small coalition.
\end{abstract}

Islamist political parties in the Middle East and North Africa (MENA) have been studied extensively since the 1990s. In the predominantly authoritarian context in which these parties have operated, most research has focused on Islamist ideology, and more recently, on electoral strategies and voters. ${ }^{1}$ With the increasing control Islamist parties have been gaining in local and national governments in MENA, understanding Islamist political practices and government performance are becoming more and more relevant.

Until recently, Islamist local governments were limited to a few cases in MENA, namely Turkey, the Gaza Strip, and Morocco. Therefore, there is not much evidence to date on Islamist government practices. A number of studies credit Islamist local governments in Turkey and Gaza with better delivery of services than that of their

Miquel Pellicer and Eva Wegner are researchers at the Institute of Middle East Studies at the German Institute of Global and Area Studies in Hamburg. They have published extensively on political participation, Islamist parties, and clientelism in North Africa in journals such as Quarterly Journal of Political Science, Party Politics, Electoral Studies, and Democratization, among others. Eva Wegner is also the author of Islamist Opposition in Authoritarian Regimes: The Party of Justice and Development in Morocco (Syracuse University Press, 2011).

This article incorporates findings that were published in 2009 as a working paper by the Robert Schuman Centre under the title "The Moroccan Party of Justice and Development in Local Government: Do Islamists Govern Differently?" The present article offers an updated and extended version of that paper and contextualizes PJD governance in terms of the practices of typical Moroccan parties. The authors would like to thank the participants those who participated in the workshop "Spaces for Change? Decentralization, Participation, and Local Governance" at the 2009 Mediterranean Research meeting and on the panel "Islamists in Government" at the 2012 DAVO conference for helpful comments.

1. See, among many others, Jillian Schwedler, Faith in Moderation: Islamist Parties in Jordan and Yemen (New York: Cambridge University Press, 2006); Carrie Rosefsky Wickham, Mobilizing Islam: Religion, Activism, and Political Change in Egypt (New York: Columbia University Press, 2002); Janine A. Clark, "Social Movement Theory and Patron-Clientelism: Islamic Social Institutions and the Middle Class in Egypt, Jordan, and Yemen," Comparative Political Studies, Vol. 37, No. 8 (2004): pp. 941-68; Carlos Garcia-Rivero and Hennie Kotze, "Electoral Support for Islamic Parties in the Middle East and North Africa," Party Politics, Vol. 13, No. 5 (Sep. 2007), pp. 611-36; Miquel Pellicer and Eva Wegner, "Socio-Economic Voter Profile and Motives for Islamist Support in Morocco," Party Politics, Vol. 20, No. 1 (Jan. 2014), pp. 116-33; Michael D.H. Robbins, "What Accounts for the Success of Islamist Parties in the Arab World?" Dubai Initiative Policy Brief (Belfer Center, Harvard Kennedy School, November 2009), http://belfercenter.ksg.harvard.edu/files/Robbins_-_Policy_Brief_-_FINAL.pdf. 
predecessors. ${ }^{2}$ At the same time, studies also have found that that corruption persisted in Islamist-led municipalities in Turkey, and that better service delivery came at high costs and increased debt. ${ }^{3}$ An aggressive stance on moral issues was softened, or at least mitigated over time. ${ }^{4}$

This article aims to contribute to the literature on Islamist political practices and government performance by studying the first cycle of local governments of the Moroccan Islamist Justice and Development Party (Hizb al- 'Adala wa-l-Tanmi$y a$, known by the acronym of its French name, PJD for Parti de la Justice et du Développement) from 2003 to 2009. The question that this article aims to answer is whether the PJD's behavior in local politics was different from standard Moroccan parties, and if so, in what ways. While there are important differences between Moroccan political parties, the literature documents a convergence on a number of party practices that we define as standard: a disregard of party organization for political decision-making and electoral mobilization, the absence of ideology and policy considerations for coalition-building, a lack of effort of individual politicians, a high tolerance toward corrupt practices, and a shared - notable-type — profile of elected officials. These characteristics act as the point of comparison when assessing the PJD's behavior in local politics in this article.

We combine a variety of sources and types of data to address the topic, including interviews with Moroccan party representatives, observation of electoral campaigns, electoral and census data, as well as audit reports from Morocco's auditors' courts. Additionally, we cite interviews with PJD mayors, as well as budget data for three PJDgoverned municipalities.

Our analysis reveals that the PJD showed a different approach to local politics governance in the stages before it had to face the realities of governing, shown for example in the importance it placed in campaign organization and the type of candidates it ran. For the PJD's performance in governance, the evidence is mixed based on government outcomes. We only find a difference between towns where the party won a significant share - above $30 \%$ - of local council seats. Only in the these towns did the PJD government appear to have effected changes, with the data showing indications of increased investment and decreased corruption, resulting in impressive gains for the PJD in the following elections. We believe that this may be due to the PJD having

2. Yezid Sayigh, "Hamas Rule in Gaza: Three Years On" Middle East Brief, No. 41 (Crown Center for Middle East Studies, Brandeis University, March 2010), www.brandeis.edu/crown/publications/meb/MEB41.pdf; Jenny B. White, "Pragmatists or Ideologues? Turkey's Welfare Party in Power," Current History (Jan. 1997), pp. 25-30; Nathan J. Brown, "Gaza Five Years On: Hamas Settles In," The Carnegie Papers (Carnegie Endowment for International Peace June 2012), http:// carnegieendowment.org/files/hamas_settles_in.pdf; Élise Massicard, “L'Islamisme Turc à L'Épreuve du Pouvoir Municipal: Production d'Espaces, Pratiques du Gouvernement et Gestion des Sociétés Locales" ["Turkish Islamism and the Test of Municipal Power: Production of Space, Government Practice, and Local Society Management"], Critique Internationale, Vol. 42, No. 1 (Feb. 2009), pp. 21-38; Ugur Akinci, "The Welfare Party's Municipal Track Record: Evaluating Islamist Municipal Activism in Turkey," The Middle East Journal, Vol. 53, No. 1 (Winter 1999), pp. 75-94.

3. Akinci, "The Welfare Party's Municipal Track Record;" Massicard, "Turkish Islamism and the Test of Municipal Power."

4. Brown, "Gaza Five Years On;" Sayigh, "Hamas Rule in Gaza;" White, "Pragmatists or Ideologues?;" Massicard, "Turkish Islamism and the Test of Municipal Power." 
greater room to maneuver in these municipalities to implement its agenda compared to towns in which the party had less support and was forced to govern with an average of five coalition partners.

The first section of this article gives a background on Moroccan politics at the national and local levels, and the normative behavior of its political parties. The second section analyzes the PJD's political operations at the local level, including its campaign in the 2003 elections and its coalition-forming practices. The third section studies government outcomes in terms of corruption and spending in areas where the PJD participated in and led local councils. The fourth section looks at the relationship between the PJD's performance and the results of the 2009 local elections, and the final section concludes.

\section{POLITICS AND PARTY PRACTICES IN MOROCCO}

The Moroccan monarchy is an electoral, but authoritarian regime. Democratic institutions play a role in policy-making, but policies against the core interests of the palace are impossible to enact. Political liberalization measures that included constitutional reforms in the 1990 s — and more recently in 2011 - have continuously increased the scope for elected representatives' influence, although they have never touched on the core of monarchical power. ${ }^{5}$ Multiparty elections have been held since the country's independence from France in 1956. Up until the late 1990s, blatant electoral fraud ensured the dominance of pro-palace parties. Since King Muhammad VI's accession to the throne in 1999, elections have become much more transparent. At the same time, redistricting has occurred before every single election in the 2000s; votebuying and more traditional clientelist practices also remain widespread.

\section{LOCAL GOVERNMENT}

The political reforms of the late 1990s and early 2000s also increased decentralization. Since the mid-1970s, municipal councils have held some prerogatives and some degree of budget control with the goal of using them as sources of patronage and co-optation for the regime. ${ }^{6}$ A new municipal charter introduced in 2002 increased the prerogatives of local councils with respect to governors, who are appointed by the king, and municipal councillors were also granted indemnities and other office-related benefits. Local budgets in most municipalities are largely self-managed, and the councils can collect taxes, and can locally organize the provision of public services.

With respect to policy-making, local councils suffer from the same restrictions as national governments. Although many local council decisions are certainly less sensitive than those of national governments, their actions are in practice

5. For more information on the political liberalization process in the 1990s, see Lise Storm, Democratization in Morocco: The Political Elite and Struggles for Power in the Post-Independence State (New York: Routledge, 2007). For a critical analysis of the 2011 constitutional reforms, see Ahmed Benchemsi, "Morocco: Outfoxing the Opposition," Journal of Democracy, Vol. 23, No. 1 (Jan. 2012), pp. 57-69.

6. Abdeslam M. Maghraoui, "Depoliticization in Morocco," Journal of Democracy, Vol. 13, No. 4 (Oct. 2002): pp. 24-32. Municipal councils existed since 1960, but had a consultative role at best. 
closely monitored by regime representatives (such as pashas in municipalities, governors in regions, and walis in provinces) on the ground. In practice, the budgets of urban municipalities also have to be approved by the interior ministry before they can be implemented. ${ }^{7}$ Moreover, the competences and powers of municipal councils remain relatively general and ambiguous. The relationship between the councils' competences and those of other national agencies and ministries remains especially vague, thus leaving a considerable margin for the regime to intervene in local government decisions.

\section{Political Parties}

While a multiparty system was already provided for in Morocco's first constitution in 1962, the recognition of the monarchy's political and religious legitimacy is a prerequisite for any party to gain and maintain legal status. However, we can divide political parties in Morocco into two types: those that are palace creations and those with a legacy of loyal opposition. ${ }^{8}$ The first type consists of parties created by the palace and those that were officially founded by public figures close to the regime. Their most important function is to organize parliamentary support for the king's political initiatives. Before the political reforms of the 1990s, these parties were, in different configurations, in government. Key parties in this group are the Popular Movement (al-Haraka al-Sha'biyya, or Mouvement Populaire), founded in 1958 by Mohand Laenser to organize support of rural notables for the regime, the National Rally of Independents (al-Tajammu' al-Watani li-l-Ahrar, or Rassemblement National des Indépendants, i.e., RNI); founded in 1977 by Ahmed 'Osman, a brother-in-law of King Hasan II; and the Constitutional Union (al-Ittihad al-Dusturi, or Union Constitutionelle), an offshoot of the RNI that formed in 1983. Since 2007, the Authenticity and Modernity Party (Hizb al-Asala wa-l-Hadatha or Parti Authenticité et Modernité) has been a powerful addition to this group. It was founded by Fouad 'Ali El Himma, known in Morocco as l'ami du roi (the friend of the king). ${ }^{9}$

The second type of political party emerged from opposition movements and had aspirations for radical political change at some point in their history. Longestablished important parties in this group are Istiqlal (in full: Hizb al-Istiqlal, the

7. Anja Hoffman, "Decentralization and Re-Centralization in Morocco: A View from the Middle Atlas," CERAM Working Paper 2013, No. 1 (2013).

8. For details on Moroccan parties, see Anouar Boukhars, Politics in Morocco: Executive Monarchy and Enlightened Authoritarianism (New York: Routledge, 2010); Jean-Claude Santucci, Les Partis Politiques Marocains à l'Épreuve du Pouvoir: Analyse Diachronique et Socio-Politique d'un Pluralisme Sous Contrôle [Moroccan Political Parties and the Test of Power: A Historic and Sociopolitical Analysis of Pluralism Under Supervision] (Rabat: Revue Morocaine d'Administration Locale et de Développement, 2001); Michael J. Willis, "Political Parties in the Maghrib: The Illusion of Significance?" The Journal of North African Studies, Vol. 7, No. 2 (Summer 2002), pp. 1-22; Michael J. Willis, "Political Parties in the Maghrib: Ideology and Identification. A Suggested Typology," The Journal of North African Studies, Vol. 7, No. 3 (Autumn 2002), pp. 1-28.

9. James Liddell, "Notables, Clientelism and the Politics of Change in Morocco," The Journal of North African Studies Vol. 15, No. 3 (Sept. 2010), pp. 315-31; Ferdinand Eibl, "The Party of Authenticity and Modernity (PAM): Trajectory of a Political Deus ex Machina," The Journal of North African Studies, Vol. 17, No. 1 (Jan. 2012), pp. 45-66. 
Independence Party), and, to its left, the offshoot Socialist Union of Popular Forces (al-Ittihad al-Ishtiraki li-l-Quwwat al-Sha'biyya or Union Socialiste des Forces Populaires, i.e., USFP). Although both parties abandoned their revolutionary aspirations in the 1970s, they have continued to call for democratic reforms to some extent. Since their co-optation by the national government in the late 1990s, both parties' calls for reforms have been dampened and clientelistic practices have become more common. ${ }^{10}$ For the more policy-oriented USFP, this has come at the price of a dramatic electoral decline. ${ }^{11}$

The third party in this group is the Islamist Justice and Development Party (PJD). ${ }^{12}$ Once the most active opposition party, it was brought into the government after winning the largest seat share in post-Arab Spring elections in 2011. The PJD emerged in the 1990s as one of two key Moroccan Islamist organizations and first participated in elections in 1997. Since then, the party has evolved into a very moderate party where an identity- or Islam-inspired political agenda (such as the protest against the reform of the personal status law) has been increasingly combined with a more socioeconomic agenda (trying to lower unemployment and reform administration). The PJD still mobilizes against the sale and advertisement of alcohol, and movies or cultural festivals it considers un-Islamic, but a large amount of its morality-based interventions have in effect been targeted at corruption. ${ }^{13}$ Indeed, it has come to identify itself as a party with an "Islamic frame of reference" and a "genuine economic and social program." 14

Although the PJD has increased its electoral support overall, its short history features considerable ups and downs. So far, the most critical moment of the party's history coincided with its entry into local politics in 2003. In that year, Islamist terrorist attacks in Casablanca created a political climate in which a party ban was not unthinkable. Under this threat, the PJD made a number of ideological and political concessions that led to its later rehabilitation. Following a 2007 electoral performance far below its expectations, the party changed its leadership in 2008 from the technocrat Saâdeddine El- 'Othmani to the more old-style Islamist leader 'Abdelilah Benkirane. The period under study in this article therefore begins with a defensive PJD in 2003 and ends with a more populist PJD in 2009.

10. The USFP left national government in 2011, Istiqlal remained in a coalition that includes the PJD.

11. Eva Wegner and Miquel Pellicer, "Left-Islamist Opposition Cooperation in Morocco," British Journal of Middle East Studies, Vol. 38, No. 3 (Dec. 2011), pp. 303-22.

12. For a study of the PJD's history, political agenda, and party organization, see Eva Wegner, Islamist Opposition in Authoritarian Regimes: The Moroccan Party of Justice and Development (Syracuse, NY: Syracuse University Press, 2011).

13. Matt Buehler, "The Threat to 'Un-Moderate': Moroccan Islamists and the Arab Spring," Middle East Law and Governance, Vol. 5, No. 3 (2013), pp. 23-24; Eva Wegner, "Islamist Inclusion and Regime Persistence: The Moroccan Win-Win Situation," in Debating Arab Authoritarianism: Dynamics and Durability in Nondemocratic Regimes, ed. Oliver Schlumberger (Stanford, CA: Stanford University Press, 2007), pp. 75-90.

14. See Matt Buehler, "Safety-Valve Elections and the Arab Spring: The Weakening (and Resurgence) of Morocco's Islamist Opposition Party," Terrorism and Political Violence, Vol. 25, No. 1 (2013), pp. 142-43. 
There is a growing literature on the challenges and shortcomings of Moroccan political parties. ${ }^{15}$ While important differences exist between Moroccan political parties, many of their practices have converged over the last decades. Most parties practice what Anouar Boukhars describes pointedly as "politics without positions." 16 In the following, we will focus on some core common characteristics of Moroccan political parties. These "standard practices" will then serve as a benchmark against which we will evaluate the PJD's practices in local politics.

A first shared feature is the irrelevance of party organizations. There is a low consideration for party committees in making key decisions — such as making coalition alliances or remaining in government or not - or in selecting candidates or party leaders. At worst, key decisions and leadership selections are made by a small group and candidates for legislative office, who often pay for good placement on electoral lists. ${ }^{17}$ Along the same lines, parties have neglected grassroots activities and building constituencies. ${ }^{18}$ This also implies that parties lack activists willing to work in election campaigns. In fact, most parties are forced to pay for canvassing. ${ }^{19}$

A second standard practice is the absence of policy or ideological considerations when building either national or local government coalitions. Instead, coalition building follows "strict opportunistic considerations," ${ }^{20}$ the overriding objective of which is to join a government. As a result, a typical Moroccan coalition consists of four or more parties, and frequently includes both palace and non-palace parties, as well as both secular and religious parties.

Third, many parties suffer from the lack of effort of individual politicians. This is shown, for example, in a high rate of absenteeism in parliament and the general unpreparedness of politicians when questioning or voting on draft laws. ${ }^{21}$ This lack of

15. Boukhars, Politics in Morocco; Myriam Catusse, "Affaires, Scandales et Urnes de Verre à Casablanca: Les Ambiguïtés de la 'Démocratie Locale' à l'Ėre de la 'Bonne Gouvernance"” ["Affairs, Scandals, and Glass Ballots in Casablanca: The Ambiguities of 'Local Democracy' and the Era of 'Good Governance'"], EUI Working Papers: Mediterranean Programme Series, No. 38 (European University Institute, 2002), http://cadmus.eui.eu/bitstream/handle/1814/1796/02_38.pdf; Mohamed Daadaoui, "Rituals of Power and Political Parties in Morocco: Limited Elections as Positional Strategies," Middle Eastern Studies, Vol. 46, No. 2 (Mar. 2010), pp. 195-219; Marina Ottaway and Amr Hamzawy, "Fighting on Two Fronts: Secular Parties in the Arab World," Carnegie Papers No. 85 (Carnegie Endowment for International Peace, May 2007), http://carnegieendowment.org/files/cp85_ secular_final.pdf; Santucci, Moroccan Political Parties and the Test of Power; Lise Storm, Party Politics and the Prospects for Democracy in North Africa (Boulder, CO: Lynne Rienner, 2013); Willis, "Political Parties in the Maghrib: The Illusion of Significance?"

16. Boukhars, Politics in Morocco, pp. 61-83.

17. Mounia Bennani-Chraïbi, "Mobilisations Électorales à Derb Soltan et à Hay Hassani (Casablanca)" ["Electoral Mobilization in Darb Sultan and the Hay Hassani (Casablanca)"], in Scènes et Coulisses de l'Élection au Maroc: Les Législatives 2002 [Behind the Scenes in the Election in Morocco: The 2002 Legislative] (Aix-en-Provence: Institut de Recherches et d'Études sur le Monde Arabe et Musulman, 2004), pp. 105-62; Daadaoui, "Rituals of Power and Political Parties in Morocco."

18. Ottaway and Hamzawy, "Fighting on Two Fronts," p. 207.

19. Bennani-Chraïbi, "Electoral Mobilization in Darb Sultan and the Hay Hassani."

20. Boukhars, Politics in Morocco, p. 64.

21. Boukhars, Politics in Morocco. 
effort was a key target of the PJD's parliamentary activities from 1997 to 2002, when it sought to establish itself as a party of hard-working and committed politicians. ${ }^{22}$

A fourth shared characteristic is widespread corrupt practices of candidates or elected officials, which can take various forms. In elections, there is a high tolerance for vote-buying. At the local level, reports of Morocco's Court of Auditors (al-Majlis al-A 'la li-l-Hisabat or Cour des Comptes, i.e., CdC) document a high amount of irregularities in public tenders, construction permits, and tax collection, as well as the misuse of municipal resources. ${ }^{23}$ Through various forms of corruption, municipal councils have become "sources of immense wealth." 24

A final shared characteristic of Moroccan parties is the demographic profile of individuals they bring into public office. Based on data published by the Moroccan interior ministry, the typical local councillor is male, relatively uneducated, and middle-aged, and works as a "peasant" ("fellah") — implying that he is likely to be a rural notable.

In the following sections, we will evaluate the PJD's local government experience from 2003 to 2009 in light of these five "standard party practices." A core message of the PJD has been a promise to be "different" than the typical Moroccan party, implying that it would not reproduce these practices. The question we seek to answer, however, is whether this promise of difference holds once the party entered local politics and local government. Hence, we will assess the role of the PJD's party organization in campaigning and decision-making, the importance of party ideology when forming local government coalitions, the profile of its elected representatives, the effort made by its local politicians, and the party's tolerance toward corrupt practices.

\section{LOCAL GOVERNMENT SETUP}

\section{ELECTORAL PREPARATions}

The PJD's 2003 election campaign displays two noteworthy characteristics when compared to the standard practices described above: the importance of the party's organization and the distinctive profile of PJD candidates in contrast to the typical Moroccan party.

The prominent role of the party's organization, manifest in all aspects of the PJD campaign, is the most striking feature of the PJD relative to other Moroccan parties. Months before the election - very early by Moroccan standards - PJD leaders in collaboration with local party activists released a full campaign strategy, consisting of a party platform, a video advertisement, and standardized slides for candidates' presentations. ${ }^{25}$ The party's promises in local elections can be summarized as a higher level of "proximity" to the voters (being responsive to their demands), to "moralize the management of public affairs" (less corruption), and to provide improved access to government services.

22. Wegner, "Islamist Inclusion and Regime Persistence."

23. Yearly reports are available at on the CdC's official website, www.courdescomptes.ma.

24. Maghraoui, "Depoliticization in Morocco." See also, Catusse, "Affairs, Scandals, and Glass Ballots in Casablanca."

25. Interview by Eva Wegner with the PJD's 2003 local election campaign coordinator, September 4, 2003, Rabat. 
Ahead of the elections, local party bureaus received funding from the central office for their campaign meetings. ${ }^{26}$ Local party chapters made considerable campaign drives, which not only included the production of local campaign materials, such as adding a video focusing on local problems, but also organizing rallies and campaign meetings in which they presented the candidates and the party platform. In these meetings, operatives put lots of emphasis on the qualifications and skills of PJD candidates. ${ }^{27}$ In the Moroccan context, it is important to highlight that local PJD activists and supporters mobilized their election campaign, rather than a centralized party leadership. Finally, local party members drew up candidate lists, although there was some important intervention from the party's central office. ${ }^{28}$ In short, the PJD's local electoral campaign was a party effort rather than an individual effort by a party leader, as is the case for most Moroccan parties.

A second distinctive feature was the profile of the PJD's electoral candidates. Table I displays the profiles of PJD elected councillors in terms of education, age, and profession, in comparison to the averages for councillors across all Moroccan parties. To determine whether the PJD's councillor profiles are mainly a product of the party's deeprootedness in urban areas, the figure also shows the profiles of USFP councillors, which is the other party with the strongest urban roots among the major Moroccan parties.

As shown in Table I, the PJD fielded candidates in these elections with a substantially higher level of education than candidates from the average Moroccan party. $61 \%$ of its candidates were university-educated compared to only $23 \%$ of candidates generally. PJD candidates were also considerably younger than those of other parties: 75\% of PJD councillors were under 45 years old compared to around $40 \%$ on average. Finally, the most common profession among PJD candidates was teaching (either in schools or at university), whereas the average candidate tended to be a "fellah" (most likely a local notable). In respect to these demographic characteristics, the USFP councillors closely resemble the average councillor. The PJD thus fielded candidates with a significantly different demographic profile than the average, as well as its main competitor in urban constituencies, the USFP. ${ }^{29}$

26. In principle, the USFP also contributed funds to local campaigns. However, USFP members in Larache and Ksar El Kébir reported that funds and other election materials never arrived on time. Interviews by the authors with USFP members, November 25, 2008, Ksar El Kébir and Larache). It is also quite common that candidates in other parties finance their own campaign. See Catusse, "Affairs, Scandals, and Glass Ballots in Casablanca;" Lamia Zaki, "Le Clientélisme: Vecteur de Politisation en Régime Autoritaire?" ["Clientelism: A Vector of Politicization in an Authoritarian Regime?"] in Autoritarismes Démocratiques: Démocraties Autoritaires au XXIe Siècle [Democratic Authoritarianisms: Authoritarian Democracies in the $21^{\text {st }}$ Century] Recherches No. 1 (2007), pp. 157-80; Bennani-Chraïbi, "Electoral Mobilization in Darb Sultan and the Hay Hassani."

27. These conclusions are based on observations of local campaigns and interviews in Salé, the Ya'qub al-Mansur neighborhood in Rabat, the Hay Hassani neighborhood in Casablanca, Meknès, Larache, and Ksar El Kébir in 2003 and 2009.

28. These interventions mainly consisted of attempts to secure the election of technocrats or other individuals thought to be able to deliver on the PJD's electoral promise of better management. See Wegner, "Islamist Inclusion and Regime Persistence."

29. The 2009 electoral campaign confirmed that the 2003 campaign was not an anomaly. The role of local and central party organizations in preparing and carrying out the campaign remained important. The profile of PJD candidates remained significantly different in terms of age, education, and profession from the average candidate profile. The 2009 campaign also suggests that an emphasis on pragmatism over Islamism is a long-term feature of the PJD's local political strategy. 
Table I. Demographic Profile of Moroccan Municipal Councillors, 2003-9

\begin{tabular}{|c|c|c|c|}
\hline \multicolumn{4}{|c|}{ Level of Education } \\
\hline Party & Primary or Less & Secondary & University \\
\hline PJD & $11 \%$ & $28 \%$ & $61 \%$ \\
\hline USFP & $44 \%$ & $30 \%$ & $25 \%$ \\
\hline all parties & $46 \%$ & $31 \%$ & $23 \%$ \\
\hline \multicolumn{4}{|l|}{ Age Cohort } \\
\hline Party & Under 45 & $45-54$ & 55 and Over \\
\hline PJD & $74 \%$ & $21 \%$ & $4 \%$ \\
\hline USFP & $47 \%$ & $36 \%$ & $17 \%$ \\
\hline all parties & $44 \%$ & $35 \%$ & $22 \%$ \\
\hline \multicolumn{4}{|l|}{ Profession } \\
\hline Party & "Fellah" & Teacher & Other \\
\hline PJD & $6 \%$ & $38 \%$ & $56 \%$ \\
\hline USFP & $27 \%$ & $18 \%$ & $55 \%$ \\
\hline all parties & $31 \%$ & $10 \%$ & $58 \%$ \\
\hline
\end{tabular}

Source: Kingdom of Morocco, Ministry of the Interior, General Directorate of Local Communities, Les Collectivités Locales en Chiffres [Local Communities in Statistics] (Rabat: Ministère de l'Intérieur, 2009).

\section{COALITION-BUILDING}

Although the PJD had developed new campaigning strategies and processes of candidate selection, coalition-building was the party's first encounter with the realities of Moroccan partisan politics. And indeed, the PJD's goal to govern led it to adopt practices and criteria for the formation of coalitions that were not that different from established practices. In essence, ideology and policy mattered very little.

In 2003, the PJD did not win an absolute majority in any town, but won sizeable shares of seats in a few. In most towns where the PJD fielded candidates, support was less than ten percent. ${ }^{30}$ This was partly due to the PJD's precarious situation after the suicide bombings in Casablanca on May 16. Following pressure from the interior ministry, the party leadership made the far-reaching decision to contest significantly fewer seats than they had planned before the attacks. Additionally, the PJD only fielded partial candidate lists in the larger cities to ensure that it could not win a majority in such places. ${ }^{31}$ These two measures obviously decreased the potential scope of PJD-led local government.

Within the constraints of relatively low levels of success and high levels of party system fragmentation, the PJD's goal in 2003 was to bring as many party mayors into office as possible. This goal could afford little to no consideration for

30. The PJD won less than ten percent of seats in 136 municipalities, between ten and $30 \%$ in 62 municipalities, and above $30 \%$ in only 13 municipalities.

31. Wegner, "Islamist Inclusion and Regime Persistence." 
differences in political agendas, as demonstrated in the coalition-formation criteria provided by the national party leadership.

The PJD's national party leadership stipulated that coalition-building should take into account the integrity and competence of other councillors, and how the respective parties had performed so far in local management. ${ }^{32}$ Noticeably, the policies promoted by other parties were not among the criteria on which local alliances were to be built. ${ }^{33}$

Indeed, PJD mayors admitted in interviews that policies played no role in the coalition-building process and that there was no coalition contract or action plan. ${ }^{34}$ Generally, PJD mayors, as well as members of their governing coalitions, confirmed that the formation of the municipal governments had followed the standard pattern in Morocco, in which the bargaining almost exclusively concerns the distribution of remunerated offices (who will be mayor, deputy mayor, and so on).

Interviews suggest that in practice, the main criterion in forming a coalition was whether it was possible to do so with people that were not completely delegitimized by previous municipal (mis)management. The PJD's tolerance of who fit into that category seems to have been rather large. When explaining their coalitions, PJD councillors argued that "nobody was $100 \%$ honest," nor was anyone "100\% bad." 35 Sometimes, though, councillors had to metaphorically "close their eyes vis-à-vis some councillors or parties" 36 because they were so objectionable. As a result, the PJD often found itself in "tough" coalitions, not from an ideological perspective, but from a personal point of view, as the party coalesced, in the words of one of its councillors, with "all sorts of people, illiterate, corrupted." 37

This evidence suggests that the PJD's approach to the makeup of local governments in 2003 was strikingly similar to standard practice in Morocco. At the same time, it is noteworthy that this disregard of policies in coalition-building was largely a party approach. In the context of the May 16 attacks, the party's explicit strategy had been to show potential voters through a moderate, accommodating governing approach that it was not to be feared. With only limited representation in certain districts and without any majorities, PJD mayors would have been even rarer had the party been more selective in its choice of coalition partners. The PJD's 2003 approach to local coalitions was thus driven by strategic considerations and did not imply an institutional socialization of its local politicians against the party's will. ${ }^{38}$

32. Interview by Eva Wegner with a PJD leader, November 17, 2003, location withheld on request.

33. Sometimes, there were political reasons why the PJD did not govern towns in which it had won the largest seat share, such as in Larache. Closely located to Ksar El Kébir, it was, in 2003 not acceptable for the PJD to govern both. Interview by the authors with Larache councillors from the USFP and the PSU, November 25, 2008, Larache).

34. In Témara, the governing coalition did draw up a small charter but this document was a "declaration of honor" and did not address content. In other cases, there was no document of any type. Interview by the authors with town mayors, November 15, 2008, Témara; November 27, 2008, Oued Zem; and November 14, 2008, Ksar El Kébir.

35. Interview by Eva Wegner with a PJD deputy mayor, November 12, 2003, location withheld.

36. Interview by Eva Wegner with a PJD deputy mayor, December 6, 2003, location withheld.

37. Interview by Eva Wegner with a PJD deputy mayor, April 12, 2004, location withheld.

38. In 2009, the PJD won absolute majorities in 14 towns and was thus less desperate to form government coalitions. The party generally attempted to form "programmatic" coalitions with the USFP, the only other party it perceived to have an interest in effective local government and in promoting democratic reforms (see Wegner and Pellicer, "Left-Islamist Opposition Cooperation in 


\section{PJD LOCAL GOVERNMENTS}

Of the 1,503 municipalities in 2003, the PJD only managed to establish 12 governments, all with coalitions. ${ }^{39}$ Table II shows some socioeconomic characteristics of these towns compared to the averages of Moroccan municipalities and urban municipalities specifically. Table III then displays the level of PJD support and the number of partners it needed to establish a coalition.

Table II shows that the PJD essentially governed in urban areas (nine out of 12 locations). These are typical Moroccan cities in terms of literacy and poverty rates, although they are slightly lower than average. However, they have a lower share of inhabitants living in slums than the average urban municipality, the exception being Témara, which has $30 \%$ of its inhabitants living in slums.

Table II. Profiles of PJD-Governed Locales vs. Moroccan Average, 2003-9

\begin{tabular}{|c|c|c|c|c|}
\hline Locale & Area & $\begin{array}{c}\text { Poverty Rate } \\
(\%)\end{array}$ & $\begin{array}{c}\text { Illiteracy Rate } \\
(\%)\end{array}$ & $\begin{array}{c}\text { Portion of } \\
\text { Population in } \\
\text { Slums (\%) }\end{array}$ \\
\hline El Guerdane & urban & 5 & 37 & 2 \\
\hline Ksar El Kébir & urban & 9.2 & 32 & 3.6 \\
\hline Oued Zem & urban & 10.6 & 35 & 8.5 \\
\hline Ouislane & urban & 13.6 & 35 & 7.6 \\
\hline Témara & urban & 8.5 & 27 & 30.7 \\
\hline Meknès & urban & 7.2 & 27 & 4.2 \\
\hline Azrou & urban & 9.4 & 31 & 6.3 \\
\hline Kasba Tadla & urban & 7.9 & 33 & 6.4 \\
\hline Khénifra & urban & 11 & 35 & 6 \\
\hline average (PJD areas) & urban & 9 & 32 & 8 \\
\hline average (nationwide) & urban & 11 & 34 & 8 \\
\hline Tabia & rural & 27 & 68 & 0 \\
\hline Issen & rural & 20.9 & 57 & 0.7 \\
\hline Had Boumoussa & rural & 10 & 59 & 4 \\
\hline average (PJD areas) & all & 12 & 40 & 7 \\
\hline average (nationwide) & all & 22 & 57 & 5 \\
\hline Source:King & & & \\
\hline
\end{tabular}

Source: Kingdom of Morocco, High Commission of Planning, "Recensement Général de la Population et de l'Habitat 2004" ["General Census of Population and Housing, 2004"], www.hcp.ma/ Recensement-general-de-la-population-et-de-1-habitat-2004_a633.html.

[Continued from previous page]

Morocco.”). Therefore, the national PJD's general policy on local coalitions was again implemented on the ground, albeit differently than in 2003.

39. This excludes four district councils led by the PJD in Rabat, Salé, Fez, and Casablanca. 
Table III divides PJD-governed towns into three groups according to the seat share the party commanded in each of these councils: a first group with more than $30 \%$, a second group from $10 \%$ to $30 \%$, and a third group below $10 \%$. Broadly speaking, the lower the seat share, the more coalition partners the PJD had. On one hand, this is natural because the smaller its own share, the larger the gap to reach the majority in a council. On the other hand, the difference is quite dramatic, jumping from as low as one coalition partner in the first group to as many as eight in the second. As we will discuss below, these different groups of localities have taken different paths under PJD-led governance.

Table III: PJD-Governed Locales and Coalition Partnerships

\begin{tabular}{|c|c|c|}
\hline Locale & PJD Seat Share $(\%)$ & $\begin{array}{c}\text { Parties in Coalition } \\
\text { (alongside the PJD) }\end{array}$ \\
\hline El Guerdane & 45.5 & 1 \\
\hline Ksar El Kébir & 40.0 & 1 \\
\hline Oued Zem & 32.3 & 1 \\
\hline Issen & 30.8 & 8 \\
\hline Témara & 25.7 & 6 \\
\hline Meknès & 25.5 & 3 \\
\hline Azrou & 20.0 & at least 4 \\
\hline Kasba Tadla & 13.8 & 5 \\
\hline Khénifra & 12.9 & n/a \\
\hline Ouislane & 12.0 & n/a \\
\hline Had Boumassa & 8.0 & 5 \\
\hline Tabia & 7.7 & \\
\hline
\end{tabular}

Sources: Interviews by the authors with PJD officials and local press reports

We will now assess two core aspects of PJD-led local governments relative to standard practice. The first is the level of corruption and mismanagement based on audit reports, the second looks at efforts made by the PJD's local politicians in investment and tax collection. Our discussion of corruption and mismanagement is based on audits of five PJD-governed towns (Ksar El Kébir, Témara, Meknès, Azrou, and Kasba Tadla) by the $\mathrm{CdC}$, while our discussion of the PJD's performance in local government is based on the evolution of budgets in three municipalities governed by the party (Ksar El Kébir, Témara, and Oued Zem).

\section{Corruption AND MismanaGement}

Empirically, corruption is difficult to assess. The assessment is perhaps more difficult in a country such as Morocco, where corruption is generally high, but is typically only prosecuted for political motives. Consequently, we rely on yearly reports of Morocco's regional auditor courts $(\mathrm{CdCs})$ that provide detailed accounts of their jurisdictions. The local $\mathrm{CdCs}$ do more than verify the accounts of a municipality, they investi- 
gate public tenders, construction and other public projects, tax receipts, expenses, and other public finances. The regional $\mathrm{CdCs}$ that are responsible for auditing the municipalities were set up in 2004. From then until 2009, regional CdCs undertook control missions in $86 \%$ of urban municipalities (144 out of 212) and in $7 \%$ of rural towns (86 out of 1,305)..$^{40}$ The recurrent observations highlighted by CdCs stated that there was no respect of the procedures for public tenders, issues relating to construction, lack of collection of a variety of taxes or fees, and waste of municipal resources. ${ }^{41}$ While the evidence from these reports does not allow us to quantify the level of corruption and mismanagement in PJD-governed towns relative to the average, the reports allow for a comparison between stated PJD practices and these recurrent issues noted by CdCs.

The $\mathrm{CdC}$ reports are sober in style, giving detailed accounts of irregularities in public expenditure and public administration. Detailed responses of the audited towns' mayors to the issues raised by $\mathrm{CdCs}$ are also included in the reports. We are thus quite confident about the quality and neutrality of the assessments themselves. Since 2007, the reports have not published the full list of audited towns, but instead the audit details a selection of towns that get "recommendations," meaning where problems were identified. It is therefore possible that further towns were audited but not included in the reports. Because political pressure against the inclusion of a badly managed town would certainly not help the PJD, we are confident that we have the full list of recommendations for PJD towns. In contrast, it is possible that more PJD towns were audited and received a clean audit.

Of all audited PJD towns that we know of, only Ksar El Kébir did not get "recommendations" from the regional CdC, suggesting that the amount of irregularities was negligible in this municipality. Audited PJD-governed towns that did get recommendations are Meknès, Témara, Azrou, and Kasba Tadla. An overview of irregularities in these towns is shown in Table IV below, organized by the recurrent problems noted above, including issues relating to the granting of construction permits, tax collection, and waste of municipal resources.

Table IV. Level of Irregularities in CDC Audits in PJD-Governed Towns

\begin{tabular}{|c|c|c|c|c|}
\hline Locale & Year of Audit & $\begin{array}{c}\text { Construction } \\
\text { Permits }\end{array}$ & Tax Collection & $\begin{array}{c}\text { Municipal } \\
\text { Waste }\end{array}$ \\
\hline Ksar El Kébir & 2005 & n/a & n/a & n/a \\
\hline Témara & 2007 & high & low & high \\
\hline Meknès & 2006 & - & high & high \\
\hline Azrou & 2006 & low & high & low \\
\hline Kasba Tadla & 2009 & low & high & high \\
\hline
\end{tabular}

Source: Annual reports of the Court of Auditors between 2005 and 2011, see Kingdom of Morocco, Court of Auditors, "Publications," www.courdescomptes.ma/fr/Page-27/publications.

40. Kingdom of Morocco, Court of Auditors, Rapport Annuel de la Cour des Comptes 2010: Partie II - Activités des Cours Régionales des Comptes [Court of Auditors Annual Report 2010: Part II - Activities of the Regional Courts of Auditors] (Rabat, 2011), www.courdescomptes.ma/upload/ MoDUle_20/File_20_53.pdf, p. 681.

41. Kingdom of Morocco, Court of Auditors, Rapport Annuel de la Court des Comptes 2008: Tome 2 [Court of Auditors Annual Report 2008: Book 2] (Rabat, 2009), www.courdescomptes.ma/ upload/MoDUle_20/File_20_49.pdf, p. 71-79. 
The first important observation is that $\mathrm{CdCs}$ did not find problems relating to public tenders in PJD-governed towns. ${ }^{42}$ In contrast, there were irregularities in all other categories, but to different extents, and with generally a low level of issues relating to construction permits but a high level of issues regarding tax collection and the waste of municipal resources. Whereas all of these actions may reflect corrupt practices, a careful reading of the reports suggests that this is less likely in the areas of tax collection and municipal resources than in the area of construction permits.

Regarding tax collection, the observations by $\mathrm{CdCs}$ do not concern new tax exemptions, but the continuation of old practices. This suggests the unwillingness or inability of PJD governments to determine the tax base accurately and to enforce tax collection, rather than corrupt practices.

The waste of municipal resources ranges from the renting out of municipal property at absurdly low rates (one building for 13 Moroccan dirhams, i.e., MAD, or roughly $\$ 1.50$ per month in Azrou), to the use of municipal resources (space, cars, furniture, etc.) by people not entitled to them, to the payment of fees such as phone bills, gasoline, and rents for all sorts of ineligible public servants, and the payment of public servants that are in fact not working for the municipality but for the executive branch (i.e., the local representatives of the interior ministry such as pashas and caïds, including 126 public servants in Témara alone). Again, these issues appear to be a continuation of practices that existed prior to the PJD's entry into office. CdCs, whenever possible, explicitly date the beginning of certain practices or contracts. And indeed, many of these predate the PJD-led governments. In this sense, the continuation of such routines again suggests not so much corrupt dealings by the PJD itself, but its inability to dramatically change entrenched arrangements, especially when these benefit the regime. ${ }^{43}$

The existence of corruption is less clear regarding construction permits or their ex post facto approval, as these were newly provided by PJD-led executives. In Témara, the key issues raised by $\mathrm{CdCs}$ were additional levels for all buildings that were previously limited to two and three floors, additional levels for a number of other buildings, and construction permits for areas that were ineligible for construction. It is not clear whether this involved corrupt practices by the PJD - or anyone else for that matter but it certainly could have.

In sum, we found that the town audits reveal a number of insights. First, only one town received a clean audit, signaling that the arrival of the PJD in town halls did not lead to a revolution of transparency and legal practices. Second, the scale of irregularities in PJD towns was not that large. ${ }^{44}$ Importantly, the irregularities do not involve

42. There was a small problem in Meknès where the terms of a public tender were modified later on so that in hindsight, the municipality had not chosen the cheapest company. See Kingdom of Morocco, Court of Auditors, Rapport Annuel 2007 [Annual Report 2007] (Rabat, 2008), www. courdescomptes.ma/upload/MoDUle_20/File_20_47.pdf, p. 509.

43. In fact, the mayor of Témara pointed out that the pasha was such an important figure for the work of the municipality that it warranted his use of municipal resources. Interview by both authors, November 15, 2008, Témara.

44. It is interesting to note that Meknès, where the mayor was later dismissed by the governor on corruption charges, does not stand out negatively in its practices, either among PJD-governed towns or more generally. This supports the notion that this was a purely politically motivated dismissal in an effort to tarnish the PJD's reputation. James N. Sater, "New Wine in Old Bottles: Political Parties 
public tenders, an issue that $\mathrm{CdCs}$ highlight as one key recurrent problem. With the exception of construction permits, many practices appear to reflect the inability of the PJD to challenge established arrangements and thereby live up to its promise of conducting itself differenly once involved in the practical details of government. Finally, it is worth noting that the town with the clean audit was one where the PJD had a high level of popular support and only one coalition partner, whereas the municipalities with recommendations had lower levels of support with the number of coalition partners ranging from three in Kasba Tadla to eight in Témara.

\section{EFFort of PJD Local Governments: The EVOLUTIon of Local Budgets}

An important way of assessing the effort and managerial effectiveness of local governments is to study their investment and revenue patterns by analyzing municipal budgets. We obtained key items of municipal budgets from 2001 to 2007 in three PJD-governed towns, Ksar El Kébir, Oued Zem, and Témara. Because we have information on budgets before the PJD came into power, we are able to uncover the impact of PJD governance.

Budgets are generally divided into current revenues and expenditures, and investment revenues and expenditures. Current revenues are the revenues earned on a regular basis (local taxes collected by the municipality, local taxes collected by the state, and part of the nationwide value-added tax, or VAT). Current expenditures are the type of expenditures that recur every year, such as salaries of civil servants, payment of debts, and other expenses. There are also investment expenditures. From the revenue side, the items used to finance investments are reserves (the accumulated wealth of the municipality), loans (borrowing), or government grants (a special VAT allocation assigned for investment). Investment expenditures include works such as roads or cultural centers; acquisition of goods such as new buildings, cars, or trucks for municipal use; and participation in national or integrated programs such as the well-known national program Villes sans Bidonvilles (Cities without Slums) to eradicate slums and relocate their inhabitants in standard housing.

The budget entries that best reflect managerial effort and competence are investment revenues and expenditures, as well as taxes collected by the municipality. Local authorities in developing countries often have problems spending their budgets and making investments due to the lack of expertise and management resources needed to program and follow multiyear investments. In Morocco, there is indeed consensus that the collectivités locales tend to accumulate too much in reserves. ${ }^{45} \mathrm{~A}$ municipality without too many reserves and with some borrowing used for investment can thus be a sign of an active local authority. Similarly, a municipality with a high level of tax collection reflects efforts to obtain resources to undertake these investments in a sustainable way.

[Continued from previous page]

under Mohammed VI," in Contemporary Morocco: State, Politics and Society Under Mohammmed VI, eds. Bruce Maddy-Weitzman and Daniel Zisenwine (New York: Routledge, 2012), pp. 9-23.

45. See Nalini Burn, Larabi Jaidi, and Hayat Zirari, Budget Local Et Genre Au Maroc [Local Budget and Gender in Morocco] (Casablanca: Association Démocratique des Femmes du Maroc, 2005) www.un.org.ma/IMG/pdf/unifem_18_fr.pdf. In a similar vein, a civil servant from the treasury that also held the office of deputy mayor of Rabat, argued that under-spending was one of the biggest problems of municipal management. Interview by the authors, November 2, 2007, Rabat. 
We first studied the evolution of investment expenditures and municipal taxes in PJD-led towns relative to the average of urban municipalities and all local authorities in Morocco (the latter including rural municipalities, provinces, and regions). The urban series offers a better comparison to PJD-governed towns, but the series including all local authorities is available for a longer period of time, including some years before and after the arrival of new local governments in $2003 .{ }^{46}$ In order to make meaningful comparisons, we have divided all budget items by the relevant population. Quantities have also been deflated using a price index with base in 2005. Thus, the numbers provided should be interpreted as dirhams per person per year in real terms. ${ }^{47}$

Graph I plots the evolution of investment expenditures and local tax extraction from 2000 to 2007 . The thin dotted lines correspond to the averages of urban and all local authorities. First, we consider investment expenditure. For both averages, there has been an important increase in investment expenditure. The increase was relatively modest until 2006 and accelerates substantially in 2007. The PJD-governed towns show different patterns. Témara starts with higher than average investment per capita and remains virtually at the same level throughout the years. Ksar El Kébir and Oued Zem, in contrast, start with investment levels far below the average but show a marked upward trend.

The specific chronological pattern in Ksar El Kébir and Oued Zem is striking. In particular, it is clear that investment expenditures rise significantly after 2004, the first year of PJD rule. In Ksar al-Kébir, the change in trend is truly dramatic, from around 20 MAD per inhabitant from 2000 to 2004, to around 250 in 2007, a more than tenfold increase. The increase is also very significant for Oued Zem, which started with even lower levels, close to zero, and was investing around 100 MAD per inhabitant by 2007. In contrast to the average, these increases were not particularly concentrated at the end of the period, but started at the beginning of the PJD-led legislature.

Municipal taxes, in contrast, show much less variation than investment expenditures. All series remain relatively flat, particularly the average of urban municipalities. PJD-governed towns show a slight upward trend, but there is no evidence of a rupture in the trend.

Thus, there is evidence of large increases in investment in Ksar El Kébir and Oued Zem, but these increases do not appear to have been financed by locally collected taxes. Offering insight into the origins of the resources for the increased investment expenditures, Graph II shows the evolution of reserves and borrowing for the three municipalities. Here, again, we observe significant differences across the PJD-governed towns. The main insight from these figures is that whereas reserve depletion seems to have played a role in Oued Zem, borrowing seems to have been relevant in Ksar El Kébir. The left panel of the figure, depicting the evolution of reserves, clearly shows

46. Data for urban municipalities come from the 2005, 2006, and 2007 activity reports of the Kingdom of Morocco, Directorate of Budget, "Rapport d'Activité de la Direction du Budget" ["Budget Directorate Activity Report"]. Data for the totality of local authorities (collectivités locales) come from a report by the finance ministry that contains a consistent series from 2002 to 2007. Kingdom of Morocco, Ministry of Economy and Finance, "Tableau de Bord des Finances Publiques" ["Dashboard of Public Finances"], Dec. 2008, available on the website of the National Observatory of Human Development, www.albacharia.ma/xmlui/bitstream/handle/123456789/31146/0901Tableau\%20 de\%20bord\%20des\%20finances\%20publiques.pdf.

47. The population data comes from Kingdom of Morocco, "General Census of Population and Housing, 2004." The price index data come from the World Bank's world development indicators. 
how reserves in Oued Zem were increasing steadily until 2004, at which point they leveled off and then started to fall. Reserves in Ksar El Kébir were also increasing and then grew to a halt in 2003 , but they were low to start with, so there was not much room for depletion in order to finance investment; reserves were maintained during the PJD tenure of office and the town resorted to borrowing. The amount borrowed was actually very large, reaching around 200 MAD per inhabitant in 2006.

\section{Graph I. Investment and Taxes in PJD-Governed Towns \\ Compared to the Moroccan Average}

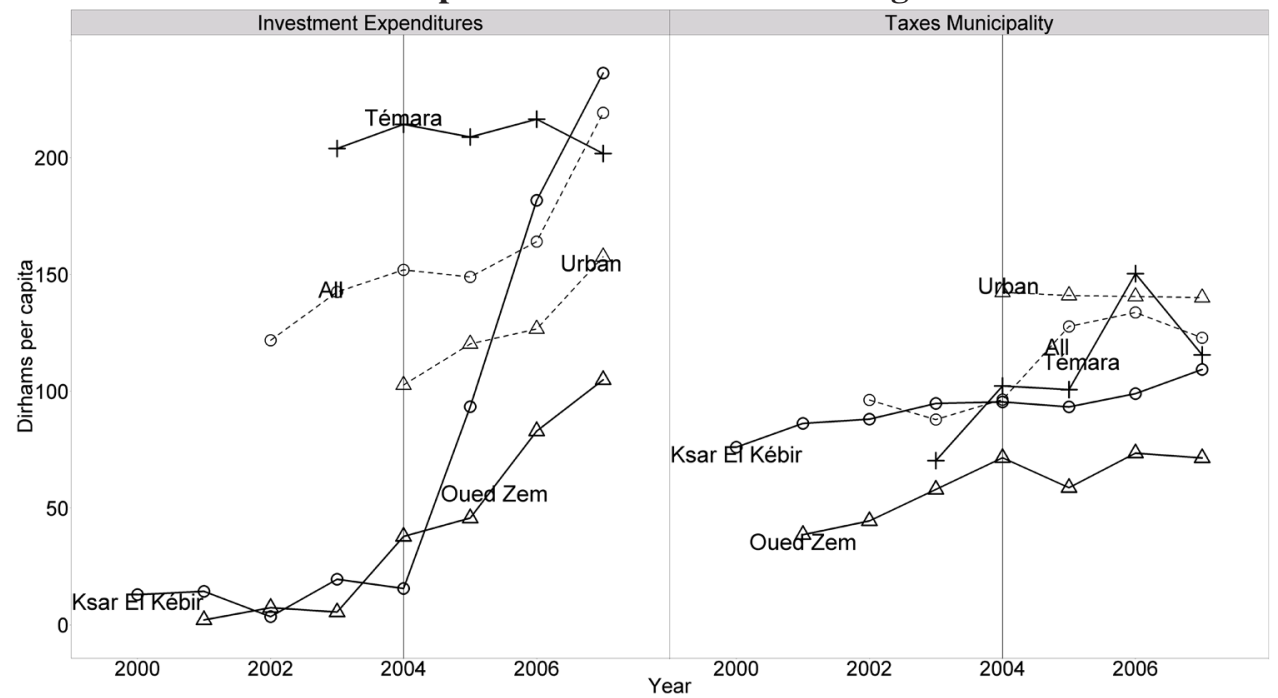

Sources: For municipality averages, see Footnote 45. For PJD-governed municipalities, data were collected by the authors from financial managers of each respective municipality.

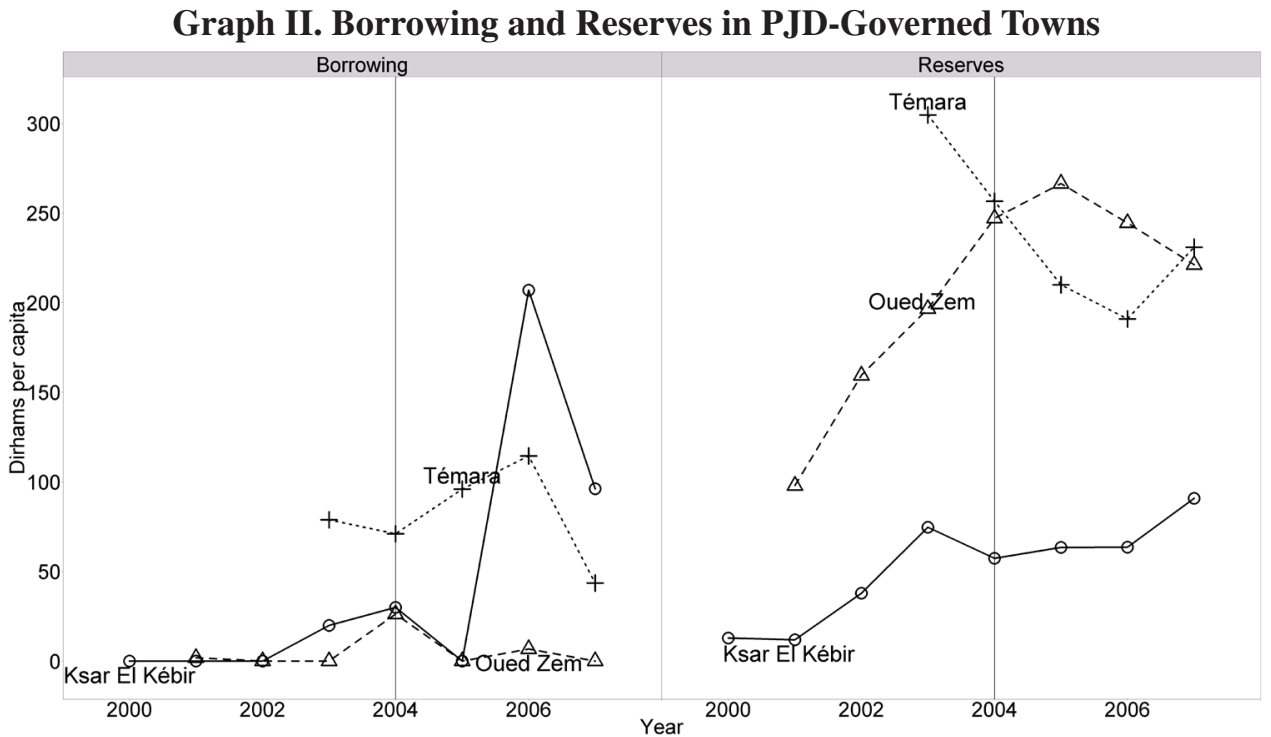

Sources: Collected by the authors from financial managers of each respective municipality. 
In sum, the performance of the different PJD governments differs significantly. The most noticeable difference is between Ksar El Kébir and Oued Zem on the one hand, and Témara on the other. The PJD seems to have made a true difference only in the former group, where investment levels increased substantially. This could be partly due to the fact that Ksar El Kébir and Oued Zem started with very low levels of investment. However, it is also worth noting that these two towns are precisely those where the PJD obtained larger levels of support in 2003, thus having more room to follow its own policy.

It is not completely clear, however, if these trends reflect good management. Tax collections have barely increased. The increase in investment appears to have been financed partly by diminishing reserves in Oued Zem and by borrowing in Ksar El Kébir, putting into question the sustainability of their model.

\section{ELECTORAL OUTCOMES}

Using the results of the 2009 municipal elections, we evaluated the electoral outcomes of PJD-led local governments. These results are a good performance indicator, even if we are unable to tell which PJD government actions voters were actually evaluating with their votes. To assess the potential role of local governance, we compared the 2009 results to their 2003 counterparts.

Table V shows the share of seats obtained by the PJD in all municipalities in the 2003 and 2009 local elections. Naturally, in 2003, the PJD obtained a much larger share of seats in the municipalities it ended up governing. Comparing the 2009 results with those of 2003, it becomes apparent that the PJD improved, on average, regardless of whether it governed or not. Moreover, the increase in seat shares is not dramatically different in places where it governed (from $23 \%$ to $30 \%$ ) compared to where it did not govern (from $1 \%$ to $4 \%$ ).

This pattern, however, masks an important distinction between places where the PJD governed with a strong mandate versus those where it did not. The third and fourth rows of the table distinguish PJD-governed municipalities according to whether they had obtained more (or less) than $30 \%$ of the seats in 2003 . The pattern is striking: among PJD-governed municipalities, the party's election performance skyrocketed in places where its 2003 results had been strong to begin with. In contrast, the PJD stagnated in places where it governed with a limited mandate. This suggests that governing made an important difference in the subsequent elections, but only in those municipalities with strong 2003 results.

Table V. PJD Results in Local Elections, 2003 and 2009

\begin{tabular}{|l|c|c|}
\hline \multicolumn{1}{|c|}{ Local Areas } & $\begin{array}{c}\text { Average } \\
\text { PJD seat } \\
\text { share, 2003 }\end{array}$ & $\begin{array}{c}\text { Average } \\
\text { PJD seat } \\
\text { share, 2009 }\end{array}$ \\
\hline Without PJD-led government in 2003 or 2009 & $1 \%$ & $4 \%$ \\
\hline With PJD-led government in 2003 or 2009 & $23 \%$ & $30 \%$ \\
\hline Where PJD received less than 30\% of seats & $15 \%$ & $11 \%$ \\
\hline \hline Where PJD received more than 30\% of seats & $37 \%$ & $68 \%$ \\
\hline
\end{tabular}




\section{CONCLUSION}

This article studied one cycle of local-level political activity by Morocco's Islamist Justice and Development Party (PJD), from its election campaign in 2003 to the outcomes of the subsequent 2009 elections. There is some evidence that the PJD's performance - in both elections and in government - stood apart from Moroccan norms. For the campaign, the PJD featured a much more prominent role of the national and local party organization as opposed to that of individual politicians. The pool of candidates that the PJD put to the forefront were also different, younger, more educated, and with more teachers and fewer "peasants" ("fellahin") — suggesting a lower presence of local notables.

Regarding actual governance, we find an interesting difference between governed places where the PJD obtained a substantial share of seats (30-49\%) and those where it did not. In towns with high PJD support, the analysis of local budgets reveals a substantial increase in investment upon the arrival of the PJD. Regarding corruption, although it is unclear if all of these towns were audited, we find that none received "recommendations" from the Court of Auditors (CdC). In those towns, the party experienced dramatic electoral gains in the subsequent local election. In contrast, in towns where it governed with low support, we do not observe significant changes upon the arrival of the PJD-led government.

We argue that these different governance outcomes might be due to constraints imposed by coalition partners. As we have seen, in places where the PJD governed with less than $30 \%$ of seats, it did so within broad coalition (an average of more than five partners). The need to satisfy these large coalitions might have limited the performance of PJD mayors. This appears to be likely at least for corruption or mismanagement where the PJD did not appear to engage in new illicit practices, but rather was rather unable to change existing arrangements.

It is important to note that, even in towns where the PJD governed with substantial support, the extent of its efficiency and the policy orientation of its rule must be qualified. Policies and ideology did not appear to influence coalition-formation. While mayoral candidates emphasized their personal appeal in addition to the PJD's. there was seldom reference to any political platform. Whereas there were indeed increases in investment, their sustainability is unclear, as they were financed either by reserves or by borrowing instead from increases in local tax collection. The evidence from subsequent electoral results is stronger and clearer, but leaves open the possibility that these improvements were the result, not of the successful provision of public services, but of clientelistic practices. 